\title{
Technogenic geodiversity: a proposal on the classification of artificial ground
}

\section{Geodiversidade tecnogênica: uma proposta de classificação dos terrenos artificiais}

\author{
Alex Ubiratan Goossens Peloggia ${ }^{\text {ad }}$, Antonio Manoel dos Santos Oliveirabe ${ }^{\text {, Adriana }}$ \\ Aparecida de Oliveira ${ }^{\text {bf }}$, Erika Cristina Nesta Silva ${ }^{\text {cg }}$, João Osvaldo Rodrigues Nunes ${ }^{\text {ch }}$
}

\begin{abstract}
${ }^{a}$ Centro Universitário SENAC; Centro Universitário Metropolitano de São Paulo - FIG-UNIMESP; Faculdade SENAI de Tecnologia Ambiental, ${ }^{\mathrm{b} U n i v e r s i d a d e ~ d e ~ G u a r u l h o s ~-~ U n G, ~}{ }^{\mathrm{C} U n i v e r s i d a d e ~ E s t a d u a l ~ P a u l i s t a ~-~ U N E S P ~(F a c u l d a d e ~ d e ~ C i e ̂ n c i a s ~ e ~ T e c n o l o g i a) ~}$

dalexpeloggia@uol.com.br, eaoliveira@prof.ung.br, reinadriana@gmail.com, ̌erikanesta@yahoo.com.br, hoaosvaldo@fct.unesp.br
\end{abstract}

\begin{abstract}
This paper's main purpose is to propose and discuss a specific geological classification (termed geotechnogenic) of artificial ground, that is, the new ground types formed as a direct or indirect result of human action, be it related to erosion or deposition processes or whilst in situ modification of the natural land. These technogenic grounds are classified into four main categories, namely the aggraded ground, the degraded ground, the modified and the mixed ground, each of them is subdivided into specific genetic types. The foundations of the proposal are derived from two main "schools" of thinking about the geological products of mankind's activity, on one hand the British works on the artificial ground and, on the other hand, the former Soviet, after Russian and east European studies on technogenic deposits and soils. These contributions have been compared with and joined to the American and Brazilian contributions on the study of technogenic deposits, leading to a comprehensive and synthetic table that can be used for basic purposes of geological and geotechnical analysis and mapping of land areas transformed by human action, as well as to aid their geomorphologic interpretation and mapping.
\end{abstract}

Keywords: technogenic ground (degraded, aggraded, modified, mixed); technogenic deposits; technogenic soils; geotechnogenic.

\section{RESUMO}

O principal propósito do presente trabalho é propor e discutir uma classificação especificamente geológica (denominada geotecnogênica) dos terrenos artificiais, ou seja, os novos terrenos formados como resultado direto ou indireto da ação do ser humano, seja esta relacionada a processos erosivos ou deposicionais ou ainda a transformações ocorridas in situ dos terrenos naturais. Esses terrenos tecnogênicos são classificados em quatro categorias principais, a saber os terrenos de agradação, os terrenos de degradação, os terrenos modificados e os terrenos mistos, cada qual por sua vez é subdividida em tipos genéticos específicos. Os fundamentos da proposta são derivados de duas “escolas” de pensamento principais sobre os produtos geológicos das atividades humanas, por um lado os trabalhos britânicos sobre terrenos artificiais e, por outro lado, os estudos soviéticos e leste-europeus sobre solos e depósitos tecnogênicos. Essas contribuições foram comparadas e agregadas às contribuições norte-americanas e brasileiras sobre o estudo dos depósitos tecnogênicos, levando a uma tabela sintética e prontamente utilizável para os propósitos básicos da análise e do mapeamento geológico e geotécnico de áreas transformadas pela ação humana, assim como para subsidiar sua interpretação e mapeamento geomorfológico.

Palavras-chave: terrenos tecnogênicos (de degradação, de agradação, modificados, mistos); depósitos tecnogênicos; solos tecnogênicos; geotecnogênico.

\section{Introduction}

The technogenic deposits can be categorised as a class of superficial formation created due the geological action of humankind, according to the original concept by Chemekov (1983). On the other hand, the artificial ground concept, as proposed by the British Geological Survey (Rosembaum et al. 2003) implies the modification of the Earth's surface due to both degradation and aggradation, each of these processes being essentially related to direct "human made" effects. Additionally, both classifications don't 
consider the characteristics of the ground built up but only transformed through human action, as described for example by Fanning \& Fanning (1989) in their article concerning man-influenced soil horizons, or by Russian and Polish researchers (e.g. Mozharova \& Gol’tsova 2008, Charzynski et al. 2013).

In this context, the scope of this paper starts with the statement that all these kinds of material (deposits, grounds, soils) have the statute of human action geological records in order to discuss the former contributions and wishing to propose a new classification of technogenic ground. This concept joins all categories of geological products "made or genetically influenced" by Man and expresses what we also propose to call technogenic geodiversity.

\section{Historical approach on the study of the geological records of human action.}

\subsection{Some ancient references}

The reference to the specific geological action of humankind is not so frequent in the literature, but it has been covered by very important authors. For example, Charles Lyell, in his Principles of Geology, cites the reference in Dante's Inferno to artificial embankments, and describes Man as an "levelling agent". References to 1700's gold mining placer deposits from Minas Gerais (Brazil), induced by the mining works, have been made by Von Eschwege in his book Pluto Brasiliensis. Edward Suess is also cited by his study of Viena's geological substratum in the 1800's (Peloggia 2005).

Afterwards, Brazilian writer Euclides da Cunha, in his 1902 book Os Sertões ("Rebellion in the Backlands"), and other works, have cited Man as a new powerful geological agent. Branner (1906), in his book Geologia Elementar, refers to "typical deposits" formed by city waste dumping. These references have almost remained absent from the main textbooks and, for this reason, have resulted in a lack of awareness in the geological education.

All in all, synthesis and references about former studies concerning human geological action are presented, for example, by Sherlock (1922), Peloggia (1994, 2005) and Oliveira et al. (2005).

\subsection{The British research: the artificial ground}

In the context of the pioneer studies cited below, Charles Lyell has been certainly one of the first geologists interested in the issue of Man's action on nature. It is interesting to cite that, in fact, Lyell himself has used the term "made ground", in his book The Geological Evidence of the Antiquity of Man, to indicate the 2 to 3 feet thick superficial layer of a section of a gravel pit containing flint implements at St Acheul (France), as viewed in figure 1 (Lyell 1863), and also filled graves material.
Lyell himself is responsible for one of the first descriptions of what can be nowadays classified as the eroded ground: the Pamona ravine (Georgia, USA), created as a result of accelerated erosion beyond deforesting, as viewed in the Principles of Geology (Lyell 1867). Lyell also describes, in the cited book, an artificial deposit from Brazil: the sepulchral mounds in Santos which is the same type of deposit (Sambaqui archaeological layers) as cited by Moraes Rego (1933) in his São Paulo State Cenozoic Formation's Classification.

Meanwhile, the British research on the subject have had a substantive enhance with the book Man as a Geological Agent, by Sherlock (1922), who provides a detailed description of Man's geological activities such as denudation (excavation and attrition), the creation of made ground, subsidence, accumulation of man-made rocks, alteration of sea-coast, circulation of water and influence over climate and atmosphere (including " $\mathrm{a}$ considerable increase in the amount of carbon dioxide", p.343). This publication can be considered one of the first really systematic studies concerning the new methodological proposal that nowadays we call technogenic approach (Oliveira 1990) and the foundation stone of this new discipline.

According to Sherlock (1922), made ground was an useful term used to refer to the débris accumulation covering the natural ground and sustaining an artificial surface level, as observed in London and other places referred to by the author, and "consisting of varied masses of human 'exuviae' [detritus] of every conceivable kind, mixed with more or less of soil and rock". Geologically, the "made ground”, for Sherlock, consists itself in an incoherent and superficial deposit analogue to a river deposit or glacial drift. This description and mapping of the made ground and other categories of artificial ground is the central point to the approach developed by the British Geological Survey (BGS) in its artificial ground classification (McMillan \& Powell 1999, Rosembaum et al. 2003, Price et al. 2004, 2011).

Be as it may, basically the BGS classification of artificial ground defines five main classes of ground produced directly or indirectly by human action, as viewed in table 1 . These classes themselves can be subdivided into types and units, but do not include the sedimentary deposits formed under genetic influence of Man's actions.

As it will be discussed later in this paper, this last type of deposit is classified as induced technogenic deposit by Oliveira (1990), who expands the former soviet concept of technogenic deposit proposed by Chemekov (1983). The made ground category corresponds to the technogenic built up deposits proposed by Oliveira (1990). 
1. Vegetable soil and made ground (1-3 feet thick)

2. Brow loam and ochreaous gravel (3 feet thick)

3. White siliceous sand with layers of chalky marl (9 feet thick)

4. Flint gravel and whitish chalky sand (10-14 feet)

5. Chalk

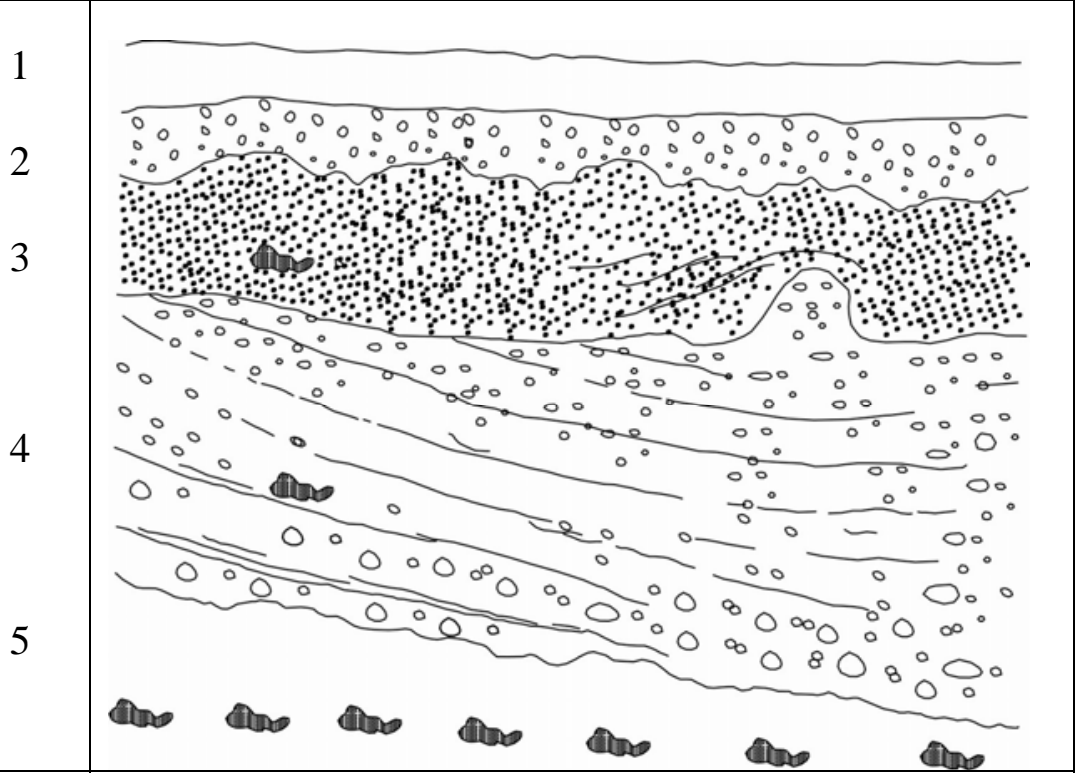

Figure 1: Lyell's (1863) section of a gravel pit at St. Acheul observed in 1860; perhaps the first “technogenic section” ever published (redrawn and adapted from the original)

Table 1: BGS Artificial Ground Classification (McMillan \& Powell 1999, Rosembaum et al. 2003, Price et al. 2004, 2011)

\section{DESCRIPTION}

\begin{tabular}{ll} 
GROUND CLASS & DESCRIPTION \\
\hline MADE GROUND & Areas where material is known to have been placed by humans on the pre-existing natural land surface. \\
WORKED GROUND & Areas where the pre-existing land surface is known to have been excavated by humans. \\
INFILLED GROUND & $\begin{array}{l}\text { Areas where the pre-existing land surface has been excavated and subsequently partially or wholly backfilled by } \\
\text { humans }\end{array}$ \\
DISTURBED GROUND & $\begin{array}{l}\text { Areas of surface or near surface mineral workings where ill defined excavations, areas of subsidence caused by the } \\
\text { workings and spoil are complexly associated with each other. }\end{array}$ \\
LANDSCAPED GROUND & $\begin{array}{l}\text { Areas where the pre-existing land surface has been extensively remodelled but where it is impracticable to delineate } \\
\text { separate areas of made ground, worked ground or disturbed ground. }\end{array}$
\end{tabular}

\subsection{The East European research: technogenic soils and deposits.}

Chemekov (1983) defines technogenic deposits as those formed as a result of human activity, having the following geological features: several ways of formation; "technogenic" transport and sedimentation processes independent from the climate and tectonics; varied composition; wide range of thickness. For the author, these deposits can be classified into three "series" according to the parameters genesis, composition and morphology: sub-aerial, subaqueous and subterranean. The main types in which the classes are subdivided are presented below (table 2):

Table 2: Chemekov's technogenic deposit types

\begin{tabular}{ll}
\hline Technogenic deposit type & Description \\
\hline Dumped & Ores extracted from mines, dumps from different enterprises, construction refuses etc. \\
Filled & Deposits which are to fill gullies, abandoned mines, quarries etc. \\
Mixed or agrotechnical & Arable and garden lands. \\
Washed up & Artificial islands, beaches, banks etc. \\
Rewashed & Dredged dumps etc. \\
Construction & - \\
Cultural layers & - \\
Precipitation & Precipitated materials in technogenic water reservoirs. \\
Linear aggradation & Deposition in technogenic streams. \\
Technogenically changes & Natural deposits with technogenic components. \\
Technogenically caused & Natural sedimentation in dammed reservoirs. \\
\hline
\end{tabular}


Antropoceno - Tecnógeno

Ter Stepanian (1988), in the same sense presented as Chemekov (1983), remarks that technogenic (or technogenous) deposits are distinguished by their great variety and characterized by clearly defined distinguishing features. They also comprise an independent genetic class (like the volcanic or alluvial ones) and can be differentiated by origin and composition. However, the author only proposes a specific classification method for "technogenic deposits of cities forming artificial soils": changed soils of natural origin, hard domestic garbage and industrial waste.

Since these former proposals, interest in the study of technogenic soils has increased in Russia and eastern Europe, resulting for example in the conceptions of technogenic soil layers and horizons presented by Mozharova \& Gol'tsova (2008) (table 3) and the classification of technogenic urban soils from Poland presented by Charzynski et al. (2013) (table 4), both related to the soil science study discipline.

Table 3: Technogenic units present at in situ underground profile (Mozharova \& Gol’tsova 2008)

\begin{tabular}{ll}
\hline Technogenic layers (techno-sediments) & $\begin{array}{l}\text { Non-soil formations purposefully inserted in the soil during technological } \\
\text { operations. }\end{array}$ \\
Technogenic horizons & $\begin{array}{l}\text { Formed under the combined effect of natural and technogenic factors of } \\
\text { pedogenesis with addiction of technogenic material. } \\
\text { Technogenically modified horizons }\end{array}$ \\
\hline
\end{tabular}

Table 4: Polish technogenic urban soil classification (Charzynski et al. 2013)

\begin{tabular}{ll}
\hline Technogenic soil units & Main characteristics and place of occurrence. \\
\hline Urbisols & Large quantities of artefacts in the profile and high horizontal and vertical variability. Urbanised areas. \\
Industrisols & Contamination with various substances. Industrial areas. \\
Gardens soils & Thick and dark humus horizons. Horticultural areas. \\
Soils of parks and laws & Technogenically transformed natural soils. \\
Necrosols & Absence of natural horizons, presence of urban layers with abrupt transitions and artefacts. \\
Ekranosols & Soils covered by pavements. \\
Constructosols & Artificial soil products built of several different layers of mineral material brought by man. \\
\hline
\end{tabular}

\subsection{American contributions to the study of Man's influenced deposits}

In the United States of America the occurrence of geological deposits related to Man's action was for the first time cited in early 1800's by Moore (1801) and Taylor (1813) (according to Roehl \& Holeman 1975), who have called them culturally accelerated deposits because of their relationship with accelerated erosion processes, in counterpoint to the geologic erosion considered as normal, in the American literature. These are genetically induced deposits so long as they are related to erosion-transport-deposition processes started by land use forms that were the consequence of the American agricultural expansion through the West.

Taking into account the origin of these deposits as resulting from the agricultural land use of drainage basins, Roehl \& Holeman (1975) have included, in the book Sedimentation Engineering, edited by the American Society of Civil Engineers (Vanoni 1975), a chapter concerning the study of these accelerated valley deposits as adequate for the formulation of parameters for sediment production measuring. This approach has been mainly based on the work from Happ et al. (1940), who have studied the deposit formation in small drainage basins in which the accelerated deposition has caused the valley aggradation. The deposits were recognised by features, like colour, texture and compactness, contrasting in comparison with the buried natural soil of the ancient valley. This procedure was used by Oliveira (1994) to measure the sediment production in small basins in the western countryside of São Paulo State (Brazil), aiming to study a hydroelectric reservoir sedimentation process. The deposit type considered above is also referred to the American literature as post-settlement alluvium (PSA) (Knox 1977), a concept also applied into research carried out in Brazil by Brannstrom \& Oliveira (1999).

At the same time the last research cited above was carried out, it was proposed by Fanning \& Fanning (1989) a classification for the highly man-influenced soils, as shown in table 5 .

This proposal deals with the material composition of the ground (soils, deposits or excavated surfaces) and also represents a first approximation to and a basis for the definition of a new concept that we propose in this paper and will be referred to below: the technogenic facies.

\subsection{The Brazilian research}

Despite some former references, the first reliable Brazilian research on the subject of Man's geological action did not appear until the 1990's, concerning induced sedimentary technogenic deposits associated to deforestation processes and built up deposits related to urban land use, as well as theoretical synthesis and the proposal for classification (e.g. Oliveira 1990, 1994, 1995, Peloggia 1994, 1997ab, 1998, Rohde 1996, Ribeiro et al. 1996). During this decade, the Brazilian 
Antropoceno - Tecnógeno

Geological Survey (CPRM 1996) proposed the use of the anthropogenic deposit category to map deposits resembling archaeological shell mounds (sambaquis), landfills, dumps and mining waste piles, all considered as being superficial formations.

Table 5: The highly man-influenced soil constituent materials (Fanning \& Fanning 1989)

\begin{tabular}{|c|c|c|}
\hline Soil materials & & Definition \\
\hline Urbic & & $\begin{array}{l}\text { Mineral soil materials that contain fragments of manufactured objects of modern man (artefacts commonly broken like } \\
\text { bricks, glass, slag, ashes, concrete, asphalt, nails, lumber, plastic, metal alloys and crushed stone). }\end{array}$ \\
\hline Garbic & & $\begin{array}{l}\text { Organic wastes of human activity (refuses that contain organic matter enough to generate significant quantities of methane } \\
\text { in anaerobic conditions) and artefacts. }\end{array}$ \\
\hline Spolic & & $\begin{array}{l}\text { Earthy (predominantly mineral) soil materials that have been moved by earth-moving equipment in surface mining, } \\
\text { highway construction etc. Contain too few manufactured object artefacts. }\end{array}$ \\
\hline Dredged & & Soil materials (usually mineral) that have been dredged through human action from waterways. \\
\hline $\begin{array}{l}\text { Scalped } \\
\text { Surface }\end{array}$ & Land & Land surfaces where previously existing soils or geologic materials have been cut by Man. \\
\hline
\end{tabular}

In what concerns the classification of these new geological deposits, Oliveira et al. (2005) highlights that the concept of correlative deposits (as records of human geological action) is an essential part for the classification of the technogenic deposits. They wouldn't exist the way they are unless due to a specific action made by humans and that can be identified and described. As it is stated, the characterization of the deposit is made possible without the necessity for distinct lithologic markers.

The first classification proposed in Brazil, Oliveira (1990), based on the proposal from Chemekov (1983), separates the technogenic deposits into three main kinds: built up deposits (resulting from direct human action); modified (natural deposits, transformed by human action), and; induced deposits (resulting from modified natural processes, like accelerated erosion).

Peloggia (1999) has reformed this classification, adding to it a broader character, and proposing the following concepts: first order (or generation) deposits, encompassing the classes that have been formerly proposed by Oliveira (1990), and; second order deposits, including the remobilised type (for example, a valley deposit created by a landslide from a former landfill in the adjacent hill slope) and the reworked type as proposed by Nolasco (2002) (for example, landfills that have suffered superimposed erosion processes).

The same author (Peloggia 1999) has presented an enhanced proposal dealing with the field description and mapping, called integrated classification, which consists of the sequential application of five parameters: genesis (implying the identification of formation processes); composition (constituent material or "lithology"); structure (mode of disposal of the materials inside the deposit); mode of placing (related landforms and geomorphologic position), and; technogenic environment (the context of production and deposition of the technogenic material). For example, according to this approach a deposit like the post settlement alluvium cited above can be described as an induced alluvium-like sedimentary technogenic deposit related to rural landscapes.

Nolasco (2002), on the other hand, has proposed another classification for technogenic deposits, based on the nature of the related human action: direct deposits, subdivided into built up deposits (deposited by man, like landfills), induced ones (resulting from the human action through other geological agents, for example as in the case of promoted landslides in mining areas), and; indirect deposits, resulting from the joined actions of mankind and other geological agents, without intervention of intentionality.

In another way, in the soil science study area, Curcio et al. (2004) proposes a classification for anthroposols, that is, soils (in a broad sense) produced by Man, conceived as soil volumes constituted by one or more anthropic layers (at least $40 \mathrm{~cm}$ thick), formed by organic or inorganic material and created only due to human interference. These soils are classified as follows (in free English version): 1) "lixic" (corresponding to the garbic concept from Fanning \& Fanning 1989) - mixed or layered soil volumes constituted by organic or inorganic human derived materials; 2) “decapithic" (corresponding to the scalped land surface concept by Fanning \& Fanning, op. cit) soil volumes exposed by human action; 3) "Somic" (reasonably corresponding to the Fanning \& Fanning (1989), concepts of spolic and urbic soil materials); 4) "Mobilitic", (corresponding in part to the BGS concept of infilled ground) - soil volumes constituted by mixed layers of other soils directly deposited through human action.

It can be remarked that, in the Brazilian geoscientific studies concerning the subject, Fanning \& Fanning (1989) classification has been applied to the description of technogenic material in general, as in the work by Silva (2013). Finally, the use of BGS artificial ground classification must also be highlighted (Price et al. 2011) as well as the recently research by Oliveira et al. (2013), Marques et al. (2013).

\section{A new proposal for classification}

The former works cited in this paper make it possible to identify and describe a great variety of ground around the world that is produced directly or indirectly through human action. We call IT technogenic geodiversity and we support the necessity for a systematic approach for the classification of this new class of geological materials.

The basis for this classification has been put together by previous research, and consists of some essential 
concepts: technogenic ground, technogenic layers, technogenic deposits, and technogenic soil horizons, as follows:

1) Technogenic (or artificial) ground: represents all new geologic substratum or land surface created directly or indirectly through human action, by the accumulation or removal of material.

2) Technogenic layer: a general term used to indicate any category of technogenic deposit or soil horizon, and specifically used to describe the ground classes in which there is a superposition of technogenic materials.

3) Technogenic deposit: a category of superficial formation (sensu Campy \& Macaire 1989) created by direct or induced deposition processes.

4) Technogenic soil horizon: an in situ soil layer modified through human action.

Starting with these basic concepts, the classification criteria used to classify all the artificial ground is as follows:

1) It is possible to be distinguished through four main classes or artificial ground (table 6): that is formed by the accumulation of geologic material; that is produced by removal or displacement of geologic material; that is created through the transformation of ancient geological material and lastly, created by the superposition of different genetic processes at the same place. The genetic processes responsible for the creation of the artificial ground are, by definition, technological processes (Fornasari et al. 1992).

2) Each of these classes of artificial or technogenic ground can be associated to one or more mapping categories by specific layers or geomorphic features used for identification, description and mapping of the technogenic geological units (tables 6 and 8).

3) Each of the main classes of technogenic ground can be subdivided into many types of technogenic ground that are created by distinct direct or induced technogenic processes. This procedure provides the essential part of the classification that is the identification of the main types of technogenic ground that has been recognized and described until today. The proposed classification has preserved the original nomenclature of the former classification, in both historical precedence and the adjustment in describing specific situations.

4) Typical examples of each type of ground and geographical Brazilian references are provided (tables 7 and 9). Finally, a general correlation between the aggraded ground, degraded ground classes and the technogenic landforms associated to their existence are demonstrated (tables 10 and 11).

\section{Final remarks}

The diagnostic criterion for technogenic ground would not exist without human intervention. All technogenic ground consists of one or more technogenic layers, of one or more categories of deposit or soil horizon, by newly exposed substratum surfaces or just by disturbed land surfaces.

All the technogenic deposits or soils are formed by the accumulation of material (aggraded ground) or the transformation of original non-technogenic material (modified ground). In both situations the constitution and aspect of the accumulated or transformed material is often an essential feature of the deposits or soil horizons. This characteristic aspect is closely related to the processes of layers formation, as well as to the human environment surrounding the new formed ground. In many cases this "aspect" is just as essential to define the genesis of the technogenic layer, in the same way as the sedimentary facies concept.

Also in the case of aggraded or modified ground classes (and, of course, in specific mixed ground types), it must be highlighted that the technogenic layers are, as we have cited previously in the introduction, essential to geological superficial formations.

A superficial formation can be defined as a geological layer with a specific spatial position (the lithosphere-atmosphere contact, flooring or subflooring situation), a relation to the ancient substratum (autochthonous in the case of soil horizons, allochthonous in the case of deposits), a site related to geomorphologic context (the technogenic land shape, in this case) and the lithological material (in the case of technogenic facies) (Campy \& Macaire 1989).

As in all superficial formations, the technogenic layers (and not only the induced technogenic sedimentary deposits) can be viewed as correlative records of the geological action of mankind, or technological process, and must be considered in stratigraphic terms. These overall ground-forming layers conforms to what was once called the anthropostrome (Passerini 1984), and the technogenic landforms related to each artificial ground conforms to settings that create technogenic land shapes and technogenic landscapes.

The human action is nowadays a main responsible for shaping the face of the Earth. This paper is an attempt to classify, in terms of hierarchy and ordination, the geological ground newly formed by these actions, and represents a special effort to increase and enhance the Brazilian contributions to the subject. 
Table 6: Technogenic Ground Classification Proposal

\begin{tabular}{|c|c|c|c|c|c|}
\hline 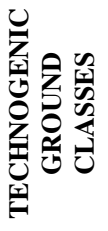 & 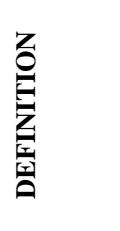 & 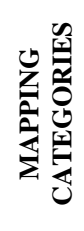 & \multicolumn{2}{|c|}{$\begin{array}{l}\text { TECHNOGENIC GROUND, } \\
\text { SOIL AND DEPOSIT TYPES } \\
\text { (GENETIC CLASSIFICATION) }\end{array}$} & $\begin{array}{l}\text { UNITS } \\
\text { TYPICAL } \\
\text { EXAMPLES }\end{array}$ \\
\hline \multirow{4}{*}{ 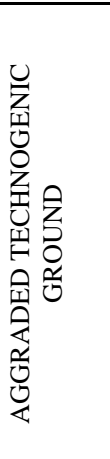 } & \multirow{4}{*}{ 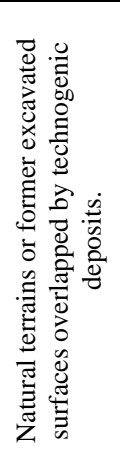 } & \multirow{4}{*}{ 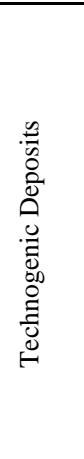 } & $\begin{array}{l}\text { Built up } \\
\text { deposits of } \\
\text { 1st generation }\end{array}$ & $\begin{array}{l}\text { Built Up Deposits } \\
\text { (deposits over natural ground: } \\
\text { made ground }{ }^{1} \text { ) } \\
\text { Built Up Infilled Deposits } \\
\text { (deposits covering worked ground: infilled }_{\text {ground }}{ }^{1} \text { ) }\end{array}$ & Landfills, embankments, dumps, waste sites. \\
\hline & & & \multirow{2}{*}{$\begin{array}{l}\text { Induced } \\
\text { deposits of } \\
1 \text { st generation }\end{array}$} & $\begin{array}{l}\text { Induced Sedimentary Alluvial Deposits } \\
\text { (valley deposits or technogenic wash) }\end{array}$ & \multirow[t]{2}{*}{$\begin{array}{l}\text { Sedimentary deposits at contemporary } \\
\text { drainage systems. }\end{array}$} \\
\hline & & & & $\begin{array}{l}\text { Induced Sedimentary Colluvial Deposits } \\
\text { (slope deposits or tech. hillwash) }\end{array}$ & \\
\hline & & & $\begin{array}{l}\text { 2nd } \\
\text { generation } \\
\text { deposits }\end{array}$ & $\begin{array}{l}\text { Remobilised Deposits } \\
\text { (Displaced Ground) }\end{array}$ & $\begin{array}{l}\text { Deposits formed through displacement or } \\
\text { erosion of former technogenic deposits. }\end{array}$ \\
\hline \multirow{4}{*}{ 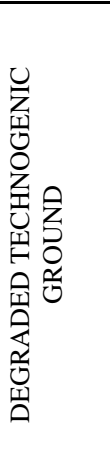 } & \multirow{4}{*}{ 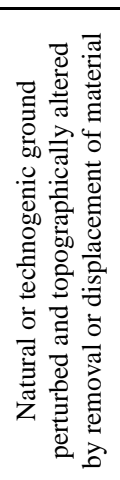 } & \multirow{3}{*}{ 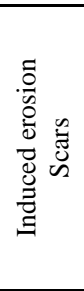 } & \multicolumn{2}{|c|}{ Eroded Ground or Land $\left(^{2}\right)$} & Gullies, rill and sheet erosion, "bad lands". \\
\hline & & & \multicolumn{2}{|c|}{$\begin{array}{l}\text { Slipped Ground or Land }\left(^{2}\right) \\
\text { (Scared ground through landslides) }\end{array}$} & Landslide scars. \\
\hline & & & \multicolumn{2}{|c|}{$\begin{array}{l}\text { Sunken Ground or Land }\left(^{2} \text { ) }\right. \\
\text { Disturbed Ground }\left({ }^{1}\right) \\
\text { (induced subsided or collapsed ground) }\end{array}$} & Sinkholes. \\
\hline & & 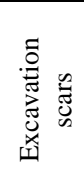 & \multicolumn{2}{|c|}{$\begin{array}{l}\text { Excavated Land } \\
\text { Worked Ground }\left(^{*}\right) \\
\text { (excavation surfaces) }\end{array}$} & Cut and fill surfaces, quarries, pits. \\
\hline 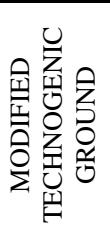 & 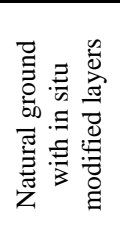 & 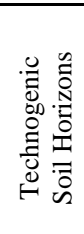 & Chemically A & [odified Soil & Contaminated soil horizons \\
\hline \multirow{2}{*}{ 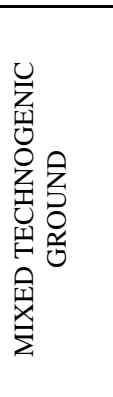 } & \multirow{2}{*}{ 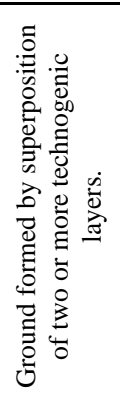 } & 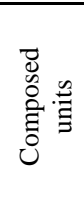 & \multicolumn{2}{|c|}{$\begin{array}{l}\text { Layered Deposits } \\
\text { (composed sections) }\end{array}$} & $\begin{array}{l}\text { Landfills over induced deposits. Landfills over } \\
\text { technogenic soil horizons. }\end{array}$ \\
\hline & & 苨: & \multicolumn{2}{|c|}{$\begin{array}{l}\text { Complex Deposits or Soils } \\
\text { (complex or undifferentiated sections) }\end{array}$} & $\begin{array}{l}\text { Landfills altered by effluents, archaeological } \\
\text { layers. }\end{array}$ \\
\hline
\end{tabular}

( ${ }^{1}$ ) Former categories from BGS classification (McMillan \& Powell 1999, Rosembaum et al. 2003, Price et al.. 2004, 2011).

$\left({ }^{2}\right)$ We suggest the use of "land" and "ground" according to the adopted geological mapping scale. 
Table 7: Main characteristics of Technogenic Ground

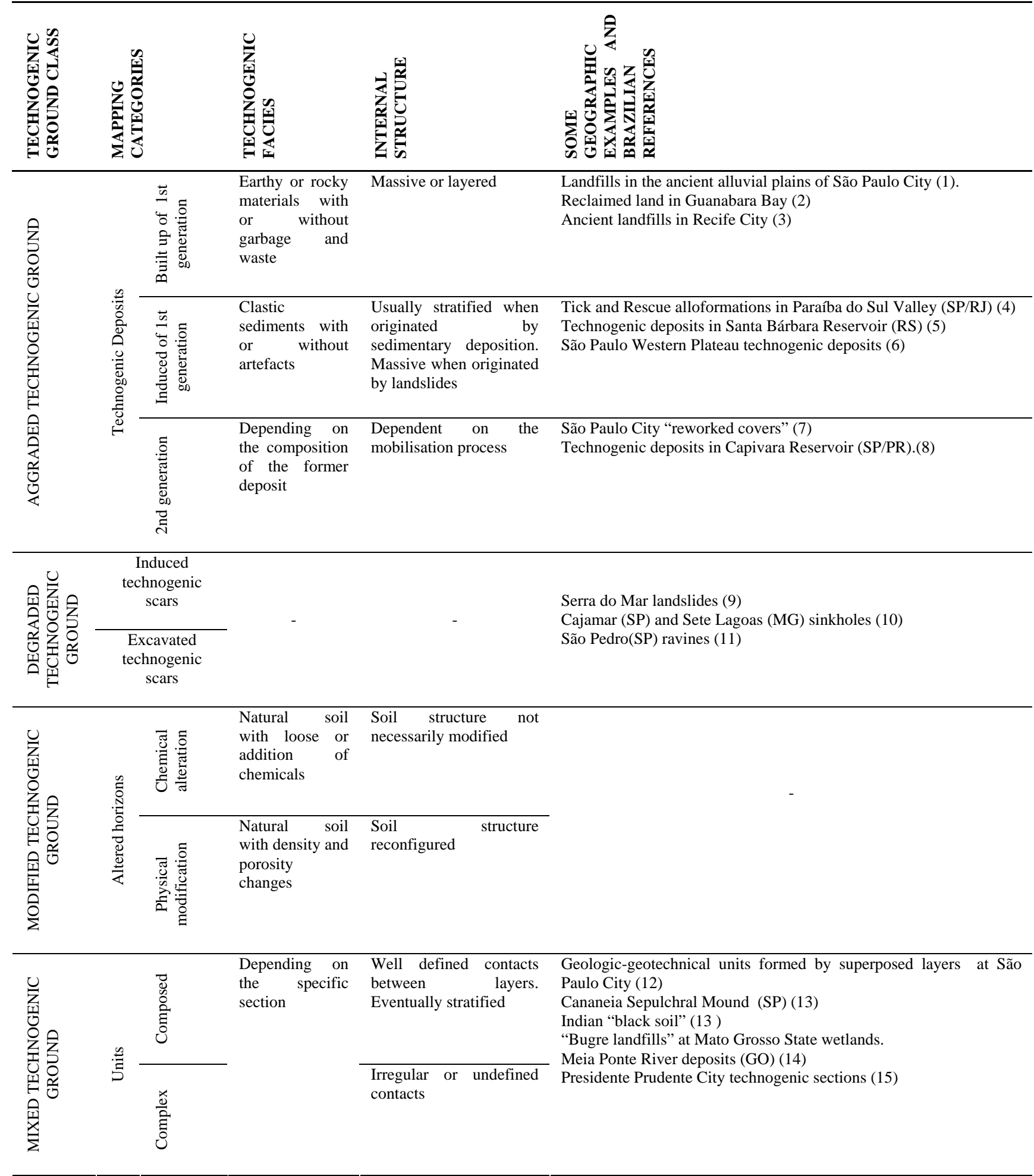

(1) Peloggia (1998), Kutner \& Bjornberg (1997), (2) DGM (1965), (3) Gusmão (1993), (4) Mello et al. (1995), (5) Korb (2006), (6) Brannstrom \& Oliveira (1999), (7) Peloggia (1994), (8) Oliveira (1990), (9) Ab’Saber (1985), (10) Prandini (1990), (11) Capellari \& Castro (1996), (12) Barros \& Peloggia (1993), (13) Kipnis \& Scheel-Ybert (2005), (14) Rubin et al. (2008), (15) Silva (2012). 
Table 8: Version in Portuguese of the Technogenic Ground Classification Proposal

\begin{tabular}{|c|c|c|c|c|c|}
\hline & & & \multicolumn{2}{|c|}{$\begin{array}{lcccc}\text { CLASSIFICAÇÃO } & \text { GENÉTICA } & \text { DE } & \text { TIPOS } & \text { DE } \\
\text { TERRENOS, SOLOS E DEPÓSITOS TECNOGÊNICOS }\end{array}$} & EXEMPLOS TÍPICOS \\
\hline \multirow{5}{*}{ 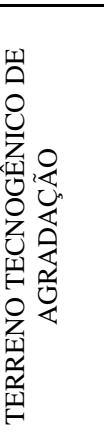 } & \multirow{5}{*}{ 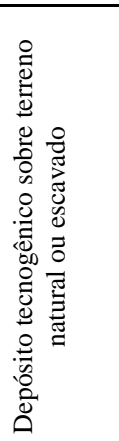 } & \multirow{5}{*}{ 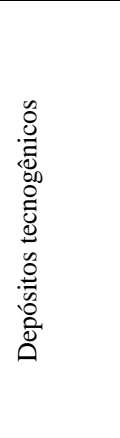 } & \multirow{4}{*}{ 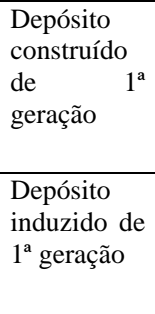 } & $\begin{array}{l}\text { Depósito Construído } \\
\text { (depósito sobre terreno natural) }\end{array}$ & \multirow{2}{*}{$\begin{array}{l}\text { Aterros em geral, diques e barragens de } \\
\text { terra, bota-foras, } \\
\text { depósitos de lixo e aterros sanitários, } \\
\text { enrocamentos. }\end{array}$} \\
\hline & & & & $\begin{array}{l}\text { Depósito Construído de Preenchimento } \\
\text { (depósito sobre terreno escavado ou erodido) }\end{array}$ & \\
\hline & & & & $\begin{array}{l}\text { Depósito Sedimentar Induzido Aluvial } \\
\text { (depósito de fundo de vale) }\end{array}$ & \multirow[t]{2}{*}{$\begin{array}{lrr}\text { Depósitos sedimentares } & \text { relacionados às } \\
\text { redes de drenagem atuais } & \end{array}$} \\
\hline & & & & $\begin{array}{l}\text { Depósito Sedimentar Induzido Coluvial } \\
\text { (depósito de encosta) }\end{array}$ & \\
\hline & & & \multicolumn{2}{|l|}{$\begin{array}{l}\text { Depósito de } \\
2^{a} \text { geração }\end{array}$} & $\begin{array}{l}\text { Depósitos formados por retrabalhamento de } \\
\text { depósitos previamente existentes. }\end{array}$ \\
\hline \multirow{4}{*}{ 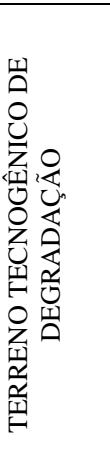 } & \multirow{4}{*}{ 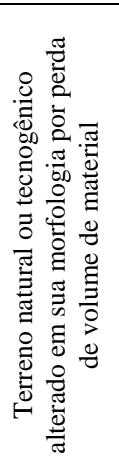 } & \multirow{3}{*}{ 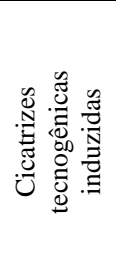 } & \multicolumn{2}{|c|}{$\begin{array}{l}\text { Terreno Erodido } \\
\text { (cicatrizes erosivas) }\end{array}$} & Sulcos, ravinas e voçorocas. \\
\hline & & & \multicolumn{2}{|c|}{$\begin{array}{l}\text { Terreno Escorregado } \\
\text { (cicatrizes de deslizamentos) }\end{array}$} & Escorregamentos em geral. \\
\hline & & & \multicolumn{2}{|c|}{$\begin{array}{l}\text { Terreno Afundado } \\
\text { (afundamentos por subsidência ou colapso) }\end{array}$} & Dolinas, poços, sumidouros, depressões. \\
\hline & & 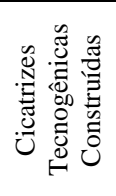 & \multicolumn{2}{|c|}{$\begin{array}{l}\text { Terreno Escavado } \\
\text { (superfície de escavação) }\end{array}$} & $\begin{array}{llll}\text { Cortes de } & \text { terraplanagem, } & \text { cavas } & \text { de } \\
\text { mineração. } & & & \end{array}$ \\
\hline \multirow{2}{*}{ 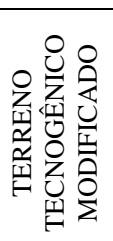 } & \multirow{2}{*}{ 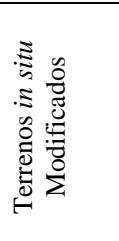 } & \multirow{2}{*}{ 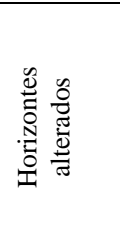 } & \multicolumn{2}{|c|}{$\begin{array}{l}\text { Solo Quimicamente Alterado } \\
\text { (horizontes com alteração química) }\end{array}$} & $\begin{array}{llll}\text { Solo contaminado com } & \text { efluentes ou } \\
\text { pesticidas. } & & & \end{array}$ \\
\hline & & & \multicolumn{2}{|c|}{$\begin{array}{l}\text { Solo Mecanicamente Alterado } \\
\text { (horizontes compactados ou revolvidos) }\end{array}$} & $\begin{array}{l}\text { Solo compactado, subsolagem de solo } \\
\text { agrícola. }\end{array}$ \\
\hline \multirow{3}{*}{ 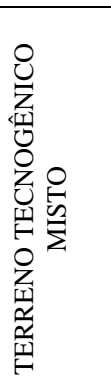 } & \multirow{3}{*}{ 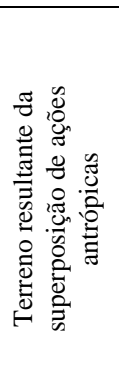 } & & \multirow{2}{*}{\multicolumn{2}{|c|}{ Camadas Sobrepostas }} & Aterro (depósito construído) sobre depósito \\
\hline & & 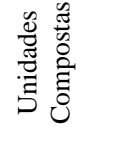 & & & $\begin{array}{l}\text { de assoreamento (induzido) } \\
\text { hou } \\
\text { horizontes de solo tecnogênico. }\end{array}$ \\
\hline & & 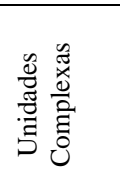 & \multicolumn{2}{|c|}{$\begin{array}{l}\text { Camadas Complexas } \\
\text { (unidade indiferenciada) }\end{array}$} & 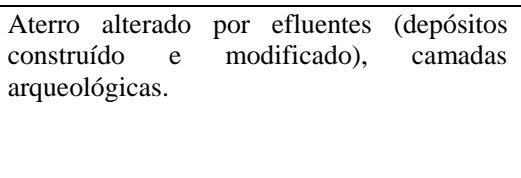 \\
\hline
\end{tabular}


Antropoceno - Tecnógeno

Table 9: Version in Portuguese of the main characteristics of Technogenic Ground

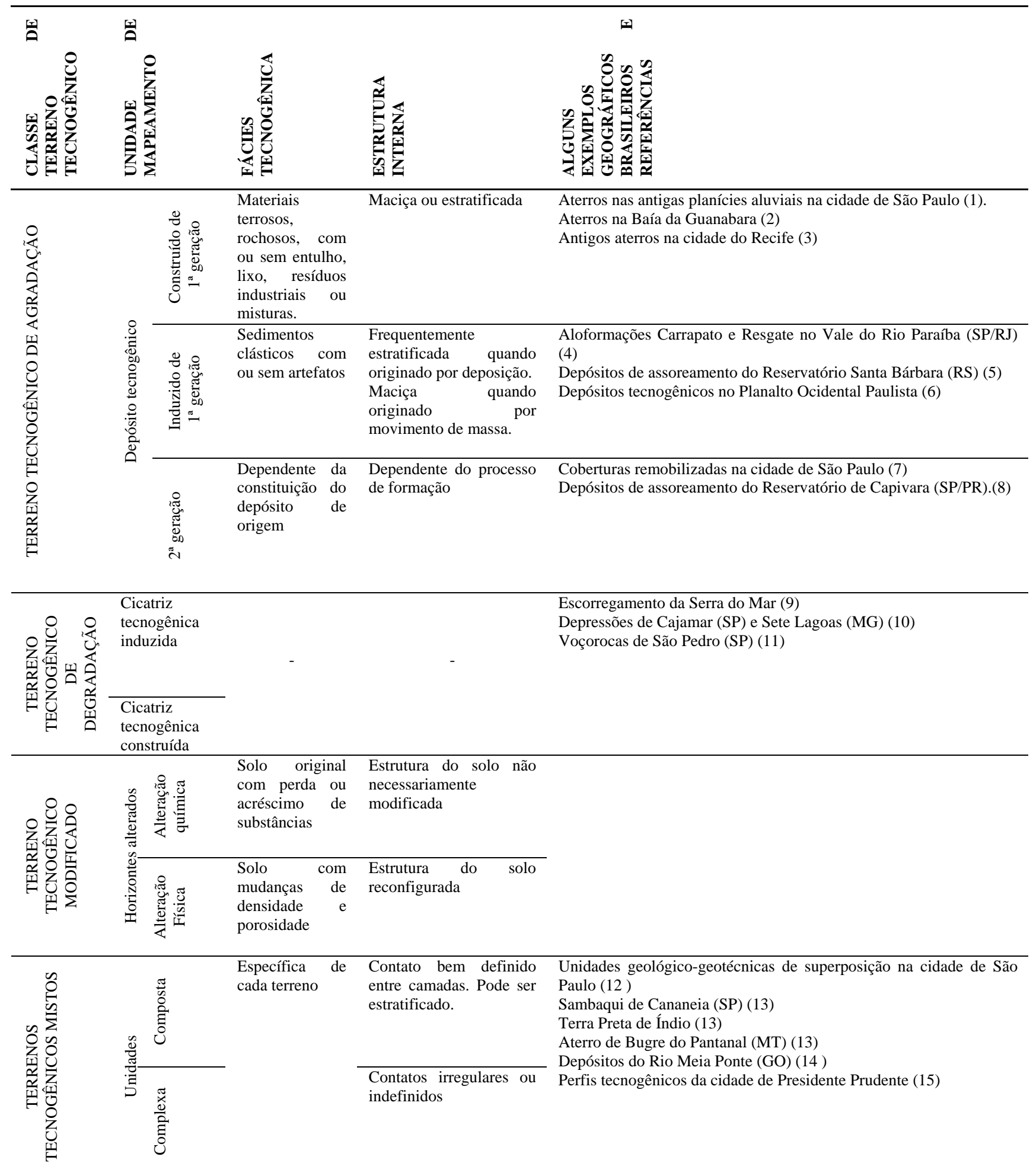

(1) Peloggia (1998), Kutner \& Bjornberg (1997), (2) DGM (1965), (3) Gusmão (1993), (4) Mello et al. (1995), (5) Korb (2006), (6) Brannstrom \& Oliveira (1999), (7) Peloggia (1994), (8) Oliveira (1990), (9) Ab’Saber (1985), (10) Prandini (1990), (11) Capellari \& Castro (1996), (12) Barros \& Peloggia (1993), (13) Kipnis \& Scheel-Ybert (2005), (14) Rubin et al. (2008), (15) Silva (2012). 
Antropoceno - Tecnógeno

Table 10: Technogenic ground classes (aggraded and degraded) related landforms (adapted from Peloggia et al. submitted)

\begin{tabular}{lll}
\hline $\begin{array}{l}\text { Technogenic } \\
\text { Ground Classes }\end{array}$ & Mapping Categories & Related Technogenic Landforms \\
\hline $\begin{array}{l}\text { Aggraded } \\
\text { Technogenic } \\
\text { Ground }\end{array}$ & $\begin{array}{l}\text { Aggraded } \\
\text { Landforms } \\
\begin{array}{l}\text { Degraded } \\
\text { Technogenic }\end{array}\end{array}$ & $\begin{array}{l}\text { Land surfaces produced through building up processes due to accumulation of material, namely } \\
\text { landfilling, or by intensification of sedimentary deposition. }\end{array}$ \\
& Landforms & $\begin{array}{l}\text { Land surfaces produced or modified by the removal of geologic material: directly by human } \\
\text { mechanical action or indirectly by human intensification of erosion, or even by natural erosion of } \\
\text { ancient technogenic deposits. }\end{array}$ \\
& $\begin{array}{l}\text { Disturbed } \\
\text { Landforms }\end{array}$ & displacement of geologic material due to induced superficial or underground mass movements. \\
\hline
\end{tabular}

Table 11: Technogenic Ground Classification Synthesis and Correlation Table

\begin{tabular}{|c|c|c|c|}
\hline $\begin{array}{l}\text { Main class of } \\
\text { technogenic } \\
\text { ground }\end{array}$ & $\begin{array}{l}\text { Type of technogenic } \\
\text { ground }\end{array}$ & Concept & $\begin{array}{l}\text { Correlation with other classifications cited in } \\
\text { this paper }\end{array}$ \\
\hline \multirow[t]{3}{*}{$\begin{array}{l}\text { Aggraded } \\
\text { Technogenic } \\
\text { Ground }\end{array}$} & $\begin{array}{l}\text { Made ground (1,2) } \\
\text { Infilled ground (2) }\end{array}$ & $\begin{array}{l}\text { Technogenic built up deposits. } \\
\text { Technogenic built up deposits covering } \\
\text { worked ground. }\end{array}$ & $\begin{array}{l}\text { Urbic soil materials, dredged soil materials, } \\
\text { spolic soil materials, garbic soil materials, } \\
\text { urbisols, constructosols, techno-sediments, urban } \\
\text { soils. }\end{array}$ \\
\hline & $\begin{array}{l}\text { Technogenic } \\
\text { sedimentary or wash } \\
\text { ground }\end{array}$ & $\begin{array}{l}\text { Technogenic wash, that is induced } \\
\text { alluvium-like technogenic sedimentary } \\
\text { deposits or colluvium-like technogenic } \\
\text { deposits. }\end{array}$ & $\begin{array}{l}\text { Cultural layers, culturally accelerated deposits, } \\
\text { accelerated valley deposits, post settlement } \\
\text { alluvium, technogenic-alluvial sediments. }\end{array}$ \\
\hline & Displaced ground & Remobilised technogenic deposit. & Reworked covers. \\
\hline \multirow[t]{2}{*}{$\begin{array}{l}\text { Degraded } \\
\text { Technogenic } \\
\text { Ground }\end{array}$} & $\begin{array}{l}\text { Eroded ground (3) } \\
\text { Slipped ground or scared } \\
\text { ground through landslides } \\
\text { Sunken or disturbed } \\
\text { ground (2) }\end{array}$ & $\begin{array}{l}\text { Erosion scars due to induced processes. } \\
\text { Slope mass movement scars due to } \\
\text { induced processes. } \\
\text { Subsidence sinkholes due to induced } \\
\text { processes. }\end{array}$ & \\
\hline & $\begin{array}{l}\text { Excavated or worked } \\
\text { ground ( } 2 \text { ) }\end{array}$ & Excavation surfaces. & Scalped land surfaces, decapithic soils. \\
\hline $\begin{array}{l}\text { Modified } \\
\text { Technogenic } \\
\text { Ground }\end{array}$ & $\begin{array}{l}\text { Chemically altered ground } \\
\text { Mechanically modified } \\
\text { ground }\end{array}$ & $\begin{array}{l}\text { Contaminated soil horizons } \\
\text { Compacted or revolved soil horizons. }\end{array}$ & $\begin{array}{l}\text { Anthropogenic soils, antroposoils, } \\
\text { technogenically modified horizons, industrisols, } \\
\text { ekranosols. }\end{array}$ \\
\hline $\begin{array}{l}\text { Mixed } \\
\text { Technogenic } \\
\text { Ground }\end{array}$ & $\begin{array}{l}\text { Complex ground } \\
\text { Layered ground }\end{array}$ & $\begin{array}{l}\text { Complex technogenic profiles. } \\
\text { Composed technogenic profiles. }\end{array}$ & \\
\hline
\end{tabular}

(1) In the original sense as cited by Sherlock (1922)

(2) According to the British Geological Survey (BGS) artificial ground classification.

(3) The classical reference to the eroded ground can be FOUND in Lyell's description, in the $10^{\text {th }}$ edition of his Principles of Geology, of the

Pamona's newly-formed ravine in Georgia (USA), originated twenty years afterward the land's native forest had been removed (Lyell 1867).

\section{Acknowledgments}

The authors are grateful to Mr. Brian Begley for his English linguistic support. We also thank the anonymous referees for their suggestions.

\section{References}

Ab’Saber A.N. 1985. A gestão do espaço natural: relembrando Caraguatatuba, 1967, para compreender Cubatão, 1985. AU Arquitetura e Urbanismo, I(3): 90-93.

Barros L.H.S., Peloggia A.U.G. 1993. Cartografia geotécnica como fundamento para recuperação de áreas urbanas degradadas: o exemplo da favela do Jardim Eliane, Município de São Paulo. In: Congresso Brasileiro de Geologia de Engenharia, 7, Poços de Caldas (MG), Anais... ABGE, v.3, p. 83-92.

Branner J.C. 1906. Geologia Elementar: preparada com especial referência aos estudantes brasileiros. Laemmert, Rio de Janeiro, 306p.

Brannstrom C., Oliveira A.M.S. 1999. Human modification of stream valleys in the western plateau of São Paulo, Brazil. Implications for environmental narratives and management. Land Degradation \& Development, 11: 424-437.
Campy M., Macaire J.-J. 1989. Géologie des formations superficielles (géodinamique - faciès - utilisation). Masson, Paris. 433p.

Capellari B., Castro S.S. 1996. Cartografia de risco à erosão em São Pedro, SP. In: Congresso Latino Americano de Ciência do Solo, Águas de Lindoia (SP), Boletim de Resumos Expandidos... Departamento de Geografia - USP.

Capellari B., Peloggia A.U.G. 2012. Degradação ambiental, sedimentação tecnogênica e reajustamento da drenagem na bacia hidrográfica do ribeirão das Sete Voltas (Taubaté, SP). In: Congresso Brasileiro de Geologia, 46, Santos (SP), Anais... SBG, CD-ROM.

Charzynski P., Bednarek R., Hulisz P., Zawadzka A. 2013. Soils within Torun urban area. In: Charzynski P., Hulisz P., Bednarek R. (eds.) Technogenic Soils of Poland. Polish Society of Soil Science, Torun, p.17-29.

Chemekov Y.F. 1983. Technogenic deposits. In: INQUA Congress, 11, Moscow, Abstracts... v.3, p. 62.

CPRM - Serviço Geológico do Brasil. 1996. Viabilizando o estudo e a cartografia das formações superficiais. A Terra em Debate 2(1): 65-66.

Cunha E. 1982 [1902]. Os Sertões: campanha de Canudos. Abril Cultural, São Paulo, 442p. 
Curcio G.R., Lima V.C., Giarola N.F.P. 2004. Antropossolos: proposta de ordem (1 ${ }^{\mathrm{a}}$ aproximação). Embrapa Florestas, Colombo, 49 p.

DGM - Divisão de Geologia e Mineralogia - MME/DNPM. 1965. Mapa Geológico do Estado da Guanabara. SF-23-Q-IV-/SF-23W-II-2. 1: 50.000 scale.

Fanning D.S., Fanning M.C.B. 1989. Soil: morphology, genesis and classification. J. Wiley, New York, 395p.

Fornasari Filho N., Braga T.O., Galves M.L., Bitar O.Y., Amarante A. 1992. Alterações no meio físico decorrentes de obras de engenharia. Instituto de Pesquisas Tecnológicas, São Paulo, $165 p$.

Gusmão Filho J.A. 1993. Risco geológico no Recife. In: Congresso Brasileiro de Geologia de Engenharia, 7, Poços de Caldas, Anais... ABGE, v.3, p.41-62.

Happ S.C., Rittenhouse G., Dobson G.C. 2008 [1940]. Some principles of accelerated stream and valley sedimentation. US Dep. Agr.Tech.Bull. 695. In: Classics in Physical Geography Revisited. Progress in Physical Geography 32(3): 337-345.

Kipnis R., Scheel-Ybert R. 2005. Arqueologia e paleoambientes. In: Souza C.R.G., Suguio K., Oliveira A.M.S., Oliveira P.E. (eds.), Quaternário do Brasil. Holos, Ribeirão Preto, p.343-362.

Knox J.C. 1977. Human impacts on Wisconsin stream channels. Annals of the Association of American Geographers 56: 212231.

Korb C.C. 2006. A identificação de depósitos tecnogênicos na barragem Santa Bárbara, Pelotas, RS. Dissertação de Mestrado, Programa de Pós-Graduação em Geografia, Instituto de Geociências, Universidade Federal do Rio Grande do Sul. 164 p.

Kutner A.S., Bjornberg A.J.S. 1997. Contribuição para o conhecimento geológico-geotécnico da bacia de São Paulo: litotipos, notação estratigráfica e feições estruturais relevantes. Engenharia 54(522): 65-73.

Lyell,C. 1863. The geological evidence of the antiquity of Man with remarks on theories of the origin of species by variation.. John Murray, London, 526p.

Lyell C. 1867. Principles of Geology. 10th ed. John Murray, London, v.1,463p.

Marques D.S., Oliveira A.M.S., Andrade M.R.M., Queiroz W., Oliveira A.A. 2013. Mapeamento de Terrenos Tecnogênicos no Município de Guarulhos, SP. Congresso da Associação Brasileira de Estudos do Quaternário, 14, Natal (RN), Anais (Resumos)... ABEQUA. CD-ROM.

McMillan A.A., Powell J.H. 1999. BGS Rock Classification Scheme. V.4 - Classification of artificial (man-made) ground and natural superficial deposits. British Geological Survey Research Report Number RR 99-04, Nottingham: BGS, 65p.

Mello C.L., Moura J.R.S., Carmo I.O., Silva T.M., Peixoto M.N.O. 1995. Eventos de sedimentação durante o Holoceno no Médio Vale do Rio Paraíba do Sul (SP/RJ) - Aloestratigrafia e Datações por Radiocarbono. In: Congresso da Associação Brasileira de Estudos do Quaternário 5, Niterói (RJ), Anais... ABEQUA /EDUFF, p.193-200 Available in www.abequa.org.br/trabalhos/anais_1995.pdf. Accessed on the 10th of December, 2013.

Mirandola F.A. 2006. Depósitos e feições tecnogênicas associados à análise de risco geológico de escorregamento: o caso da Favela Real Parque, São Paulo. Exame de Qualificação de Mestrado. Instituto de Pesquisas Tecnológicas, São Paulo.

Mozharova N.V., Gol'Tsova T.V. 2008. Some features of technogenic soil layers and horizons in the zones of underground gas storages. Moscow University Soil Science Bulletin 63(3): 97-103.

Nolasco M.C. 2002. Registros geológicos gerados pelo garimpo. Lavras Diamantinas - BA. Tese de Doutorado, Pós-Graduação em Geociências, Instituto de Geociências, Universidade Federal do Rio Grande do Sul. Porto Alegre. 316p.

Oliveira A.A., Andrade M.R.M., Oliveira A.M.S., Queiroz W., Marques D.S. 2013. Depósitos Tecnogênicos em loteamentos urbanos de Guarulhos, SP. Congresso da Associação Brasileira de Estudos do Quaternário, 14, Natal (RN) Anais (Resumos)... ABEQUA, CD-ROM.

Oliveira A.M.S. 1990. Depósitos tecnogênicos associados à erosão atual. In: Congresso Brasileiro de Geologia de Engenharia, Salvador... Anais, ABGE: ABMS, v.1, p.411-415.
Oliveira A.M.S. 1994 Depósitos tecnogênicos e assoreamento de reservatórios: exemplo do reservatório de Capivara, Rio Paranapanema SP/PR. Tese de Doutorado, Programa de Pósgraduação em Geografia Física, Departamento de Geografia. Universidade de São Paulo, 211p. v1 e v2.

Oliveira A.M.S. 1995. A Abordagem Geotecnogênica: a Geologia de Engenharia no Quinário. In: Curso de Geologia Aplicada ao Meio Ambiente. São Paulo, Instituto de Pesquisas Tecnológicas/ Associação Brasileira de Geologia de Engenharia, p.231-241.

Oliveira A.M.S., Brannstrom C., Nolasco M.C., Peloggia A.U.G., Peixoto M.N.O., Coltrinari L. 2005. Tecnógeno: registros da ação geológica do homem. In: Souza C.R.G., Suguio K., Oliveira A.M.S., Oliveira P.E. (eds.), Quaternário do Brasil. Holos, Ribeirão Preto. p.363-378.

Passerini P. 1984. The ascent of the Anthropostrome: a point of view on the Man-Made Environment. Environmental Geology and Water Sciences 6(4): 211-221.

Peloggia A.U.G. 1994. As coberturas remobilizadas: depósitos tecnogênicos de encostas urbanas no município de São Paulo. Solos e Rochas 17(2): 125-120.

Peloggia A.U.G. 1997a. A ação do homem enquanto ponto fundamental da geologia do Tecnógeno: proposição teórica básica e discussão acerca do caso do Município de São Paulo. Revista Brasileira de Geociências 27(3): 257-268.

Peloggia A.U.G. 1997b. A classificação dos depósitos tecnogênicos urbanos. In: Simpósio de Geologia do Sudeste, 5, Penedo (Itatiaia, RJ), Atas... SBG, p.181-183.

Peloggia A.U.G. 1998. O Homem e o Ambiente Geológico: geologia, sociedade e ocupação urbana no Município de São Paulo. Xamã, São Paulo, 271p.

Peloggia A.U.G. 1999. Sobre a classificação, enquadramento estratigráfico e cartografação dos solos e depósitos tecnogênicos. In: Peloggia A. U. G. (org.) Estudos de Geotécnica e Geologia Urbana (I). Prefeitura do Município de São Paulo/ GTGEOTEC, São Paulo, p. 35-50.

Peloggia A.U.G. 2003. O problema estratigráfico dos depósitos tecnogênicos. In: Congresso da Associação Brasileira de Estudos do Quaternário, 9, Recife (PE), Anais... Avaliable in http://www.abequa.org.br. Accessed on the 24th of September, 2012.

Peloggia A.U.G. 2005. A ação geológica do homem nos clássicos da geologia, com especial atenção aos Principles of Geology de Lyell. In: Congresso da Associação Brasileira de Estudos do Quaternário, 10, Guarapari (ES), Anais... 2005. Available in http://www.abequa.org.br. Accessed on the 22nd of September, 2012.

Peloggia A.U.G., Silva E.C.N., Nunes J.O.R. 2014. Technogenic landforms: conceptual framework and application to geomorphologic mapping of artificial ground and landscapes as transformed by human geological action. Quaternary and Environmental Geosciences (submitted).

Prandini F.L. 1990. Karst and urbanization: investigation and monitoring in Cajamar, São Paulo State, Brazil. In: Simpson, E.S.; Sharp, J.M. Jr. eds. Selected papers on Hydrogeology. International Association of Hydrogeologists, Washington, v.1, p.53-66.

Price S.J., Ford J., Kessler H., Cooper A., Humpage A. 2004. Artificial ground: mapping our impact on the surface of the Earth. Earthwise 20: 30-32.

Price S.J., Ford J.R., Cooper A.H., Neal C. 2011. Human as major geological and geomorphological agents in the Anthropocene: the significance of artificial ground in Great Britain. Phil. Trans. R. Soc. A 369: 1056-1086.

Rego L.F.M. 1933. As formações cenozóicas de São Paulo. Anuário da Escola Politécnica de São Paulo, Ano II, 2a série, p.231-267.

Ribeiro M.C.L., Moura J.R.S., Mello C.L., Salgado C.M.S. 1996. Caracterização pedológica de depósitos coluviais tecnogênicos no Médio Vale do Rio Paraíba do Sul - Região de Bananal (SP/RJ). In: Congresso Brasileiro de Geologia, 39. Salvador (BA). Anais... SBG. 2:493-495.

Rosenbaum M.S., Mcmillan A.A., Powell J.H., Cooper A.H., Culshaw M.G., Northmore K.J. 2003. Classification of artificial (man-made) ground. Engineering Geology 69(3-4):399-409.

Roehl J.W., Holeman J.N. 1975. Accelerated valley deposits. In: Vanoni V. A. (ed.) Sedimentation Engineering, New York (NY), 
Antropoceno - Tecnógeno

Am. Soc. Civ. Eng., ch. 3, p. 382-389 (Manuals and Reports on Engeneering Practice n.54).

Rohde G.M. 1996. Epistemologia ambiental: uma abordagem filosófico-científica sobre a efetuação humana alopoiética. Edipucrs, Porto Alegre, 231p.

Rubin J.C.R., Oliveira A.M.S., Saad A.R., Brito G.S. 2008. Amostragem dos depósitos tecnogênicos associados ao Rio Meia Ponte na área urbana de Goiânia (GO). Revista Brasileira de Geomorfologia 9(2): 3-14.

Sherlock R.L. 1922. Man as a geological agent: an account of his action on inanimate nature. H.F. \& G. Witherby, London, 372p.

Silva E.C.N. 2012. Formação de depósitos tecnogênicos e relações com o uso e ocupação do solo no perímetro urbano de Presidente Prudente - SP. Dissertação de Mestrado, Programa de PósGraduação em Geografia, Faculdade de Ciência e Tecnologia, Universidade Estadual Paulista, Presidente Prudente, 183p. Available http://www.athena.biblioteca.unesp.br/F/?func=find-b0\&local_base=BPP. Accessed on the 14th of November, 2013.

Silva M. 2013. Impactos ambientais decorrentes da instalação de depósitos tecnogênicos na Ilha de Santa Catarina, SC, Brasil. Dissertação de Mestrado, Pós-Graduação em Geografia, Departamento de Geografia, Universidade Federal de Santa Catarina, 89p.

Ter-Stepanian G. 1988. Beginning of the Technogene. Bulletin of the International Association of Engineering Geology, 38:133-142.

Vanoni V. (ed.). 1975. Sedimentation Engineering, Am. Soc. Civ. Eng., New York, 743 p.

Recebido 19 de dezembro de 2013

Aceito 06 de maio de 2014 